\title{
Poststructuralism against Poststructuralism: Actor-Network Theory, Organisations and Economic Markets
}

\author{
Contact Details: \\ John Michael Roberts \\ Sociology and Communications \\ School of Social Sciences \\ Brunel University \\ Uxbridge \\ Middlesex \\ UB8 3PH
}

Tel: 01895266377

Fax: 01895203018

Email: John.Roberts@brunel.ac.uk

\section{Short Bio:}

John Michael Roberts is currently a senior lecturer in sociology and communications at Brunel University. His main interests are on the public sphere and public space, free speech, globalisation, new media, the regulation of everyday life and the changing nature of the state. His latest book is The Competent Public Sphere: Global Political Economy, Dialogue and the Contemporary Workplace (Palgrave 2009).

Published in European Journal of Social Theory, vol. 15, no. 1, 2012. 


\title{
Poststructuralism against Poststructuralism: Actor-Network Theory, Organisations and Economic Markets ${ }^{1}$
}

\begin{abstract}
In recent years actor-network theory (ANT) has become an increasingly influential theoretical framework through which to analyse economic markets and organisations. Indeed, with its emphasis on the power of social and natural concrete 'things' to become contingently enrolled in different networks many argue that ANT successfully draws attention to the complex intermeshing of (e.g.) new technologies and social actors in organisations and markets across spatial divides from the local to the global. The paper argues however that within its own method of abstraction and research methodology ANT separates 'concrete' and 'contingent' economic markets and organisations from their abstract, necessary and virtual capitalist form. This means that ANT will tend to over-identify with how concrete-contingent actor-networks are performed in empirical economic markets and organisations at the expense of analysing how such empirical contexts are also internally mediated through abstract capitalist processes such as that of surplus value extraction. This, in turn, creates a number of difficulties in how ANT investigates economic markets and organisations. These critical points are made by recourse to the Marxist poststructuralism of Deleuze and Guattari as well as through conventional Marxist ideas.
\end{abstract}

Word count: 9280

\section{Introduction}

Many commentators argue that capitalism has made a transition towards a 'new' informational economy mediated through concrete and contingent, or concretecontingent, social networks, brand images, new media, immaterial labour located in occupations such as IT and telemarketing, and so on (for excellent summaries see Doogan 2009; Williams 2007). One recent influential poststructuralist school of thought in this debate has been that of actor-network theory (ANT). Indeed, with its emphasis on the power of concrete 'things' to become contingently enrolled in different networks ANT arguably represents the quintessential concrete-contingent poststructuralist

\footnotetext{
${ }^{1}$ I greatly appreciate the comments of the external referees and also the help of Gerard Delanty. The usual disclaimers remain.
} 
approach to studying economic markets and organisations. For example, ANT explores the world through a radical methodology in which no ontological division is assumed to exist between social and natural actors and objects. ANT thus believes that 'no actor is inherently strong or weak' because 'strength comes from associations' (Dolwick 2009: 39) between a variety of natural and social actors in a network. Such a methodological viewpoint recasts many old questions in a new light. For instance, the perennial problem of where to identify power in society is rethought because for ANT power no longer has a central authority but instead travels across a number of concrete-contingent actornetworks. Power is therefore 'always local; in situ rather than transcendent' (Fox 2000: 859) and this approach would seem to chime well with how contemporary markets and organisations now operate through concrete-contingent networks of interacting social and natural actors (e.g. people, mobile phones, online shopping, and credit cards) across spatial divides.

This paper argues however that by focusing on concrete-contingent relations ANT researchers lose a critical analytical edge in their theoretical armoury in how they might account for the way in which organisational and economic 'actor-networks' are refractions of, and fold into, abstract and immanent capitalist processes. In other words, the abstract contradictory form of capital, particularly its inherent tendency towards crisis and exploitation of labour power, is not separate from concrete-contingent practices as ANT believes, but instead 'provides the very background and terrain for the emergence of shifting-dispersed-contingent-ironic-and so on, political subjectivities' (Žižek in Butler et al. 2000: 108; original emphasis; see also Albritton 2007: 166-8; Fine 2005: 93-6; 
Gibson-Graham 2006: 90-95; Jessop 1990: 292-7; Žižek 2002: 190). Yet rather than reject the analytical usefulness of poststructuralist accounts per se, criticisms against ANT's conceptualization of organisations and economic markets are developed in part through the Marxist poststructuralism of Gilles Deleuze and Félix Guattari; a theoretical position which insists that (abstract) systemic powers in society are both heterogeneous and multiple and must be reproduced in concrete social forms, although this often occurs in a contingent manner (see also the useful discussion in Newman 2007: 34-5 on different poststructuralist camps).

In more specific terms the paper addresses two distinct problems with ANT. First, by investigating concrete-contingent actor networks associated with an empirical object of analysis ANT scholars tend to ignore the dualist and contradictory ontology within the immanent form of capitalism itself. At a high level of abstraction, or plane of immanence, this ontology is based on the separation of labour from the means of production and is mediated through the separation of use-value (the 'concrete') from value (the 'abstract'), which in turn reproduces further contradictions and dualisms in a variety of concrete capitalist forms. For its part ANT explores the 'concrete' and 'contingent' side of these dualisms and in so doing presents a partial critical picture of social relations (Kirsch and Mitchell 2004). Problems with this account are demonstrated in respect to some of ANT's methodological and empirical work on organisations. Second, ANT's method leads it to misrecognise concrete-contingent 'things' as being the cause of capitalism rather than its effects (cf. Žižek 1997: 100-101). Such a standpoint therefore displaces the abstract contradictory form of capital onto concrete-contingent 'things' and often onto the 
spectral effects of those 'things' (e.g. brands and product images). Problems with this account are shown in respect to some ANT work on economic markets.

To begin the main arguments the next section first sketches out an immanent method of abstraction through the work of Deleuze and Guattari and Marx. These ideas will then be applied in subsequent sections to identify several weaknesses in ANT's use of research strategies to explore organisations and economic markets.

\section{An Immanent Method of Abstraction}

According to Deleuze and Guattari it is important to develop concepts that make sense of, and arise within, immanent social relations that comprise underlying, or virtual, historically specific capacities, potentials and powers. But what are immanent social relations? One notable illustration of an immanent system is that of capitalism. For example, the contradictory virtual event, or abstract 'cause', of capitalism - the separation of labour from the means of production - is continually being reproduced in its 'effects' at a number of actual and concrete levels (e.g. the workplace, the privatisation of

public space, or the strengthening of corporate intellectual property rights). What this means, as Read (2003: 32) observes, is that the cause of capitalism is immanent in its effects and so must remain to an important degree 'unlocalizable'; the cause of capitalism cannot be found merely in the empirically given. In the words of Deleuze: 'immanence is not immanent to substance; on the contrary, substance and its modes are in immanence' (Deleuze 2007: 389; original emphasis). 
Subsequently an immanent event for Deleuze and Guattari is, as Patton (2010: 71) maintains, an incorporeal abstraction whose virtual existence appears in a state of affairs only in modified forms. For Deleuze and Guattari, then, concepts should be created that not only respond to problems thrown up by actual states of affairs but which can also relate these problems to 'the plane of immanence presupposed by the concept' (Deleuze and Guattari 1994: 81). For example, the Marxist concept of surplus value expresses a pure immanent event of alienation and exploitation associated with the separation of labour from the means of production and seeks to address a variety of problems in actual and virtual spheres of capitalism. Concepts are therefore created to make sense of such pure immanent events and are assessed by their usefulness in understanding the complex problems thrown out by specific events at actual and virtual 'layers' of a historical system 'that sometimes knit together and sometimes separate...' (Deleuze and Guattari 1994: 51). Furthermore, concepts should aim to express the intensity of contradictory becoming, change and movement of an immanent system (Deleuze and Guattari 1994: 40). Marx's concept of surplus value, for example, expresses the movement and contradictions of immanent relations of capitalist exploitation. Methodological limits will therefore arise if one explores the changing nature of immanent systems through universal and transcendent concepts that fail to capture such movement.

Three further observations can be made at this juncture about this immanent methodology. First, the 'realist' reading of Deleuze and Guattari being presented is different in some respects to similar realist approaches in the social sciences. For example, many critical realists similarly investigate underlying causal powers at work in 
society but do so at a transcendent level of analysis (see Bhaskar 1978). From a Marxist poststructuralist standpoint problems are evident with this approach. In the first instance, there is no necessity in this critical realist approach to explore causal powers within a historically specific evolving social system like capitalism. Therefore causal powers are often abstracted without taking account of their capitalist form (see Roberts in Dean et al, 2006: chapter 3 for a more detailed explanation of this point). This often implies that critical realists fail to fully consider the causal potency of historically specific social powers exactly because they disavow the unlocalizable expressions of pure immanence of a historical system. Notably, for example, critical realists argue that causal powers in the social world are reproduced in human actions and in social structures. However, some social powers of immanence in capitalism remain relatively autonomous of human actions and social structures. As Brown (2007) notes, the historical peculiarity of capitalism is that the pure quantity of socially necessary labour time taken to produce commodities causally affects exchange ratios across a system-wide range of commodities irrespective of its material embodiment in the qualities of any actual commodity or in the actions of any actual worker (Brown 2007: 137-42). Moreover, many critical realists stress that causal powers are ontologically separate from the actual domain (see Kaidesoja 2007). Marxist poststructuralists, on the contrary, dialectically conceptualise powers and the actual domain as being distinct but nevertheless unified entities of historical systems.

Second, and related to the previous points, it is important to distinguish a plane of immanence from a plane of organisation. The latter plane refers to how an actual form of 
life emerged by describing how it arose and what 'hidden' principles organise it (Deleuze and Guattari 1988: 292-3). Missing from this account, however, is a focus on virtual planes of immanence; those underlying potentials, powers, and capacities of a historical system that fold over and refract into one another in a rich ontological 'absolute horizon' (Deleuze and Guattari 1994: 38). We will see in subsequent sections that ANT tends to focus on planes of organisation at the expense of planes of immanence.

Finally, and related, by focusing on immanence one can begin to attend to those ideas and practices internally related to specific virtual powers, capacities, and so on, which might conceal, justify, and lead to specific immanent contradictions and dilemmas being misrecognised as natural by participants in a research context. To give another illustration, Marx (1988) demonstrates how at an abstract level of analysis the immanent contradiction in capitalism between use-value and value dialectically unfolds into the commodity, which now appears as a concrete 'thing', and money, which now appears as the universal commodity of exchange. Under these circumstances the immanent necessity of alienation, exploitation and ceaseless accumulation of capital is mystified, hidden and naturalized (see Postone 1986: 308; see also Tinker 2005: 113-14). This analysis can of course be developed and studied through further planes of immanence and organisation (for similar perspectives see also Larrain 1983; Sayer 2009; Žižek 1997).

In the rest of the paper these observations are applied to critically explore how ANT investigates organisations and economic markets. The next section begins this task by setting out some of the broader characteristics of the method of abstraction employed by 
ANT.

\section{ANT and the Concrete-Contingent Method of Abstraction}

Some suggest ANT is not a 'method' as such in the sense that it is not a 'comprehensive theory' which makes general claims but rather assembles different methods together depending on what object is under investigation (Gad and Jensen 2010: 59). When one reads works by ANT scholars there is however a clear message that emerges which implores social researchers to investigate concrete-contingent relations. Consider for example Büscher and Urry's dismissal of social theories which aim to investigate ““underlying” grammars, orders, rules or structures...' (Büscher and Urry 2009: 104). Büscher and Urry suggest instead it is more 'challenging' and 'rewarding' to examine society through the concrete and everyday methods that people use themselves to make sense of and to order their social activities. Included in this abstraction is the necessity to explore the mobile relationship between humans and everyday concrete objects and meanings (e.g. iPods, designer labels, roads, buildings, everyday markers of gender, sense of place, mobile phones). This is to understand how 'various assemblages of humans, objects, technologies and scripts' (Büscher and Urry 2009: 102) are neither preordained nor statically produced (Büscher and Urry 2009: 109) but are rather contingently linked together in a relatively durable and stable 'system' through a constant process of negotiation between a number of concrete human and non-human actors (Büscher and Urry 2009: 102). 
Büscher and Urry clearly identify ANT as being theoretically influential in how they think about society. And it is easy to understand why this is so. A key concept in ANT is that of 'actants' and this refers primarily to the contingent coming together of human and non-human actors through concrete networks of heterogeneous materials. For ANT an important question is how various concrete actants are contingently mobilised, contrasted, and then held together - or ordered - in and through organisational entities (Law 2003: 6). Organisations are thus translation devices insofar that they order actants into a recognisable network, ensuring that actants are best theorised as being part of ongoing performative translation (see MacKenzie 2004) and therefore remain contingent, mobile and uncertain (cf. Clegg 1989). The aim for ANT, then, is to analyse how the social is a performative ensemble 'produced, assembled, collected, or kept up' (Latour 2005: 184) through actor-networks which are themselves in a constant process of being performed by daily routines.

ANT's insights have been used to explore both organisations and micro activities in the global economy. In respect to the former some use ANT's ideas on translation to understand how accountancy constructs a specific arrangement of numbers which go on to inscribe themselves into organisational settings, technologies, and networks. In this instance accountancy numbers act as 'facts' which ask new questions about the way an organisation functions, problematise a set of existing organisational work practices, and assemble and translate actants into new actor-networks. Far from being neutral, then, accountancy numbers carry the potential to mobilise and order new ways of looking at work practices in an organisation, move various employees to take unique courses of 
action in line with the numbers, and translate new goals of management to employees as commonsense (Baxter and Chua 2003: 102; Lowe 2001: 77). Of course, and as Alcouffe et al. (2008) argue, the ability of a particular accountancy device to be mobilised into relatively stable organisational networks beyond an immediate accountancy community is often a long drawn out affair. Moments of stabilisation - or what Callon (1986) names as the moment of interessement - often involve overlapping strategies whose success cannot be known in advance (Alcouffe et al. 2008: 14; see also Rodden et al. 2008).

In respect to the latter, Latour suggests there is no need to look for 'invisible agencies' and/or 'jump to structure' when studying globalisation. Instead, Latour argues that it is important to trace network movements from one place to another place. 'There exists no place that can be said to be "non-local". If something is to be "delocalized", it means that it is being sent from one place to some other place, not from one place to no place' (Latour 2005: 179; original emphasis; see also Jones III, et al. 2007; Jensen 2007). For Latour, this methodological move ensures that the concrete specificity of a 'micro' context is examined through its network relationships with other contexts thus bringing into focus a more 'macro' perspective. Amin (2004) utilises such a perspective when he argues that globalisation is best theorised as 'a new spatial ontology that thoroughly disrupts the dominant spatial ontology of territorial units of organisation and scalar regulation that we have become used to' (Amin 2004: 224). He encourages us to move away from thinking about globalisation 'as the unfolding of an immanent capitalist logic' to instead investigate globalisation 'as a performance' (Amin 2004: 225; see also Latour 
2005: 184). This allows one to take account of the 'inscription of recursive relations' through which everyday material objects become embedded in global networks.

Entire network architectures - their flow lines, nodes, spaces, contours - and all their actants - key players, codes, rules, technologies, symbols, calculative practices, employees, buildings, terminals - are made to work to hold the shape of the field of action and to channel rewards and exercise influence in certain directions (Amin 2004: 225-6; emphasis added).

How global finance is presented to us in the public sphere, for example, is not as a homogeneous self-contained media image or coherent structure but, instead, is presented through a complex series of everyday concrete performative assemblages incorporating the likes of financial experts, popular financial lifestyle magazines, financial Reality TV programmes, credit cards, and so on (Clark et al. 2005; Thrift 2001).

Now that some basic characteristics of ANT's method of abstraction have been presented the next section begins the process of outlining an immanent critique of ANT's method of abstraction by firstly looking at how this method is applied to research on organisations. It will be shown that ANT's reluctance to explore how abstract contradictory processes are reproduced at a concrete and contingent level in organisations lead to intractable problems within the remit of its own theoretical framework.

\section{ANT, Research Methodology and Organisations}

To understand the enrolment of heterogeneous actors ANT researchers often favour 
qualitative methods because these are thought to best capture the complexity, mobility, and messiness of actor-networks (cf. Law and Urry 2004). One notable qualitative methodology in this respect is that of 'thick description'. Usually associated with the anthropologist Clifford Geertz (1993) who was primarily interested in the hermeneutic question of how participants interact with and gain meaning from everyday symbolic objects to create unified narratives of their world, ANT's preferred thick description is to follow a 'semiotics of materiality' that studies how all entities, both social and natural, are produced in relations (Law 1999: 4). This is a more radical methodology than a hermeneutic perspective because ANT is not so much interested in a variety of relatively meaningful and unified narratives held by human actors towards symbolic concrete objects, as it is in how a 'thing' itself 'has been allowed to be deployed as multiple and thus allowed to be grasped through different viewpoints, before being possibly unified in some later stage depending on the abilities of the collective to unify them' (Latour 2005: 116; original emphasis). This means that a 'thick description of... situated, distributed and material' (Mcfall 2009: 279) things is only useful for ANT to the extent that it opens up possibilities to investigate how specific 'ontologies' are firstly assembled together through heterogeneous materials.

A good starting point as any to examine this methodology in practice is Whittle and Mueller's study which employs both ANT and a thick description in order to understand how a variety of materials about the 'idea' of being 'enterprising', 'flexible' and 'innovative' were enrolled at a UK telecommunications firm, TeleCO. Amongst other things, Whittle and Mueller describe how consultants not only set about achieving this 
task by constructing a network at TeleCO by (e.g.) generating internal alliances with other employees but also how they problematised the existing accounting mechanisms in the organisation through heterogeneous materials - an MBA dissertation, sales pitches, databases, accountancy, and so on. Other 'micro-tactics' were soon employed by consultants to realise their aims such as billing departments for work they undertook for them. Overall, then, what we get from Whittle and Mueller's analysis is something akin to a 'thick description' of a plane of organisation insofar that they document how management consultants built a concrete-contingent network at TeleCO that enrolled other employees into an enterprise discourse. By first providing this type of description Whittle and Mueller show how multiple perspectives around 'things' at TeleCO came to be translated by consultants into a new enterprise discourse, who also managed to maintain their legitimacy as spokespersons for this discourse (Whittle and Mueller 2008: 457). Nevertheless, there are at least four related difficulties in utilising this sort of approach when studying organisations.

One methodological dilemma, first, lies with the way that thick descriptions employed by ANT are mediated through an 'ontologically relativist' research strategy; or the manner in which ANT examines 'how organizational forms emerge' (Lee and Hassard 1999: 399; original emphasis) through planes of organisation inhabited by concrete-contingent actants. As Law (2009) suggests, 'realities are only real in particular networks or systems of circulation. This means...that realities are not real outside the chains of practices that perform them' (Law 2009: 242; original emphasis). 'Truths' obtained through research are therefore not 'universal' (Law 2009: 242) but are rather performative domains in 
which different 'realities' compete with one another through different concretecontingent actor-networks. Nevertheless, apart from making somewhat obvious statements about (qualitative) social research (e.g. that 'truths' are not universal) this type of methodology enourages ANT researchers to explore the meaning of actor-networks in an actual and empirical plane of organisation without necessarily relating them to different planes of immanence. Indeed, by ignoring these immanent presuppositions ANT researchers are often transformed into descriptive recorders of the 'hidden principles' of concrete-contingent relations, narratives and stories they observe in the relativist confines of planes of organisation (cf. Simakova and Neyland 2008); the latter of which are then believed to bring about 'a synthesis of things' in an empirical context (cf. Deleuze 2007: 389).

In addition, without a focus on immanent processes the research claims made by ANT about an organisation often remain ambiguous. Whittle and Mueller for instance note that changes in accountancy practices at TeleCO led to higher levels of anxiety amongst some employees around "whether they would "survive" in the competitive marketplace for ideas within TeleCO' (Whittle and Mueller 2008: 456). Yet the lack of a more 'abstract' and 'immanent' reading of these competitive processes - by not for instance relating enterprise discourse to immanent capitalist processes of increased work intensification associated with neoliberal ideology and practices (see Fairclough 2000; Green 2006; Keat 1991; Roberts 2009) - implies that observations about such anxiety at TeleCO remain unclear. One might simply argue, for example, that levels of anxiety identified are merely normal expected attributes of organisations which arise from time to time in a 
competitive working environment.

Second, some of the concepts applied by ANT to make sense of problems observed in organisations lack a basis to make critical evaluations. A notable illustration in this respect is Whittle and Mueller's use of the concept 'resistance'. They apply this concept to make the point that consultants at $\mathrm{TeleCO}$ were aware of the necessity to overcome the 'resistance' of other employees within the organisation towards their (i.e. the consultants) new 'enterprising' consultancy role (Whittle and Mueller 2008: 457). Naturally, the concept 'resistance' has obvious evaluative and ideological overtones and denotes amongst other things a challenge to those who hold power and legitimacy to govern (cf. Roberts 2008). Whittle and Mueller's use of this concept in their study is akin to this particular meaning. But by not being clear about the broader immanent context of why 'resistance' is used as a concept to analyse the problems at hand rather than, say, another concept such as 'dissent', it is unclear how we can judge the ideological form of such 'resistance' in the first place. What broader immanent contradictions and movements is 'resistance' aiming to overcome? And is this positive or negative?

Third, and related to the previous point, this dilemma is unsurprising considering that ANT remains wedded to a rather general and historically non-specific theory of domination in which power is seen to be widely dispersed throughout an organisation in a variety of concrete-contingent actants (e.g. accountancy, bodies, texts, interactions, technology and nature; see also Law 1991). ANT subsequently rejects an immanent approach which aims to discover underlying 'virtual' powers at work in society and how 
these powers move and change because it believes such an approach reduces the complexity of concrete-contingent 'things' to the status of predefined 'objects'. For its part ANT does not presume 'objects' simply exist but considers how concrete heterogeneous actants survive as complex gatherings and associations around 'matters of concern' which make a 'thing' exist and 'maintain its existence' (Latour 2004: 246). By focusing on these 'matters of concern' ANT theorists argue that they understand more clearly how 'management and organizational realities are not the given order of things and as such could be otherwise' (Alcadipani and Hassard 2010: 426) and thus power becomes 'de-naturalised'. Problematically, though, power is defined so broadly in this account, in the sense that power potentially encompasses every empirical material object, as to be in danger of being rendered meaningless.

Cuganesan's application of ANT to explore the role of accounting numbers in a wholesale financial services business - FinCO - to enact and calculate customer intimacy provides an illustration of the issues at stake here. Cuganesan (2008: 79) defines calculation as 'the process by which an entity is rendered knowable for the purposes of action upon that entity (or others)'. For FinCO, the focus on customer intimacy was concerned to calculate the strategic issues and challenges of customers within their industry and to anticipate the reactions of customers to services offered by FinCO. Cuganesan goes on to document in empirical detail how novel actor-networks of calculation came to be inscribed at FinCO through the actions of a newly created 'Customer Research Unit' (CRU), whose remit was think about how FinCO might use market research information to ensure customers were better aligned to FinCO and so 
improve the latter's competitive position (for other similar studies see also Alcouffe et al. 2008; Frandsen 2009; Mouritsen et al. 2001).

However, Cuganesan proceeds to merely sketch out and describe power struggles around these set of calculations between various groups at FinCO. Indeed, while Cuganesan (2008: 85) observes that FinCO developed its customer intimacy strategy after becoming concerned of competitive pressures both domestically and globally, these competitive pressures are not worked through 'unlocalizable' immanent social processes. Everyday accountancy practices for instance presuppose an 'unlocalizable' immanent capitalist mode of calculation whereby the separation of labour from the means of production grants capital the power to measure labour in terms of units of time and measure the exchange of seemingly equivalent units of labour (Hadden 1994: 61). This power is tied in with capital's capacity to break each workplace down into quantifiable measurable assets such as costs of use-values in production in the guise of machinery and commodities waiting to be sold (Bryer 2006: 564-5; see also Toms 2005). These processes alter their form through different contradictions, dilemmas and pressures as they fold over and are refracted into other concrete manifestations of capitalist workplaces. Harvie and Milburn (2010) note for instance that one way value is measured more concretely in organisations is by establishing a 'connection between the organization's "performance" in each identified and isolated activity and its financial performance - shareholder or market value, the external measure of value. (Thus, the value-producing labours are made commensurable in the final instance by the market.)' (Harvie and Milburn 2010: 634). But by concentrating mainly on concrete-contingent 
accountancy practices Cuganesan overlooks how new immanent financial pressures exerted themselves upon FinCO or how they came to be internalised in power struggles about accountancy numbers. Thus it is difficult not to make an alternative and somewhat banal conclusion that the problems experienced at FinCO were just normal differences of opinion amongst management about how best to implement new policies.

Fourth, and related to the previous points, there is sometimes no necessity for actornetwork theorists to employ the transcendent concepts they do in order arrive at many of their descriptive and generic conclusions. In fact the often generic nature of their thick descriptions means that the concepts used are quite compatible with other theoretical approaches in the social sciences and humanities. For instance, much of what Whittle and Mueller describe could be incorporated to a Gramscian perspective, especially the role which the consultants played at TeleCO. After all, consultants seem to perform a role analogous to what Gramsci (1986) terms as 'organic intellectuals', namely those individuals who articulate (or 'mediate' in Whittle and Mueller's terminology) a dominant set of beliefs and ideas within the lived commonsense and experience of others in order to win hegemony for a specific social project. It is not clear therefore exactly why Whittle and Mueller prefer the generic categories of ANT over other social theories. Application, status and use of the analytical categories of ANT therefore frequently remain in doubt.

In the next section we continue and develop this assessment through the second point of critique. By looking at how ANT investigates economic markets it will be possible to 
focus on its one-sided emphasis on concrete-contingent relations. Unfortunately, one consequence of this is that actor-network theorists often misrecognise concretecontingent economic 'things' as being the cause of capitalism rather than its effects (Žižek 1997) which is in turn reproduces a weakened critical theory of markets.

\section{ANT, Economic Markets and Over-identification}

A widely held belief of ANT is that an investigation of 'structures' places undue pressure on a researcher to look for stabilities and routine behaviour in an organisational context over and above how stability is achieved, negotiated and performed amongst a wide variety of actants (Munro 1999: 431). When analysing economic organisations and markets, then, many ANT theorists prefer the advice given by Latour. 'Don't focus on capitalism, but don't stay stuck on the screen of the trading room either: follow the connections, "follow the actors themselves"' (Latour 2005: 179). As Hudson (2008: 433) indicates, it is exactly through following connections - or performative networks - that ANT usefully highlights the often complex, diverse and contested meanings of sociotechnical transformations of economic goods and practices through their transportation from one place to another (see also Barnes 2008; Castree 2002; Holifield 2009; Mayall 2007).

ANT is therefore interested in studying economic markets as 'socio-technical arrangements or agencements' (STAs) (Callon 2007: 140). These refer primarily to specific combinations of heterogeneous human, material, technical and textual devices which, depending on their combination with one another, gain the capacity to act in 
various ways (Çalişkan and Callon 2010: 9). STAs are especially prominent in what has become known as the new economy (e.g. information communication technologies [ICTs], knowledge, and the service sector) where a wide variety of different products are objectified into packages, or 'things', in order to be valued in unique ways (Çalişkan and Callon 2010: 7). Elsewhere, for example, Callon et al. argue that contemporary new economy markets create heterogeneous actor-networks that qualify, i.e., attach, detatch and re-attach, the cognitive and reflexive potentials of a consumer's system of action onto a specific product (Callon et al. 2005). Of importance to the competitive nature of contemporary economic markets in the new economy, then, is their ability to mobilise intellectual capabilities of consumers (Callon et al. 2005: 40). This much is clear when Callon et al. observe that with new information and communication technologies the 'logic of singularization reaches its peak':

With information renewed on the screen, with links and cross-references, and with scroll menus that multiply options from which users can and must choose, the Internet is a machinery that is entirely oriented towards the singularization of products (Callon et al. 2005: 42; emphasis added).

But Callon goes further in his analysis when he makes the strong claim that economic markets enact the context for economic statements to be made; an enactment that economic statements have already bargained for by making their statements in the first place. According to Callon and Muniesa (2005), for example, economic calculation 
through statements not only establishes distinctions between economic 'things' but also set courses of actions for those things. Each specific economic good is subsequently valuable to the extent that it is firstly detached from other economic goods through for example algorithmic statements so that it can then be assigned with a specific identity ensuring that new social attachments are made between itself and targeted consumers. New attachments also require other people, objects, institutions and technologies (e.g. designers, marketers, advertisers, packagers, shopping centres etc.) to create an ordered network associated with the economic good in question. As Finch (2007: 130) notes, Callon's analysis on these points is different from other perspectives in economic sociology such as Granovetter's (1984) arguments for the embedded nature of markets. Callon insists instead that markets emerge through a disembedding process in which actors are 'disentangled' from various ties and then stabilised within a specific actornetwork, while consumers qualify products and then singularize and personalise their use of these products (see also Callon 1999: 185-6; Preda 2007). However, three related problems are evident in Callon's and ANT's exploration of economic markets.

First, Callon makes his argument by insisting that economics needs to be defined broadly as comprising a whole array of human and non-human objects and statements. Nevertheless, as both Fine (2003: 481) and Santos and Rodrigues (2009: 992) note, such a general argument is in danger of reducing market behaviour to economics exactly because economics is so broadly defined by Callon and by ANT more generally. Callon himself admits as much to the latter point when he claims that his theory of economic markets is applicable to a 'diversity of markets' ranging from non-capitalist to capitalist 
societies (Çalişkan and Callon 2010: 4). Or, elsewhere, Callon et al. insist that the 'struggle for attachment and detachment is at the heart of competition' (Callon et al. 2005: 40; added emphasis). Contemporary capitalism for Callon is thus constituted through a number of generic, transcendent and universal actor-networks struggling at a concrete-contingent level over what to attach and detach themselves to and from. Capitalism as a historically specific social system of accumulation does not therefore figure in Callon's narrative.

Second, arguments which claim that the economy is 'new' because of a supposed dominance of concrete-contingent STAs confuses cause with effect (cf. Žižek 2009: 1401). The Marxist poststructuralism of Deleuze and Guattari is once again instructive in highlighting some of the difficulties of this position. They argue that under capitalism technical machines like ICTs certainly appear to obtain a degree of independence from industrial capital; the latter of which for Marxist theory is the main generator of surplus value. Similarly, it seems to be the case that as Callon argues STAs in the new economy obtain independent qualified codes through the singularization of products. However, continue Deleuze and Guattari, qualified codes are only part of the story. The great innovation of capitalism is that through the historical emergence of industrial capital social flows of life are in fact decoded through the incessant and immanent drive to procure surplus value irrespective of meaningful coded beliefs or qualities (Deleuze and Guattari 1984: 268). And even if it is indeed the case that new advanced machines have the power to connect together 'radically heterogeneous...goods...human activities, and technical, industrial and scientific processes' (Guattari 2009: 268; original emphasis) it is 
still nevertheless wrong to only focus on how these factors 'standardize, compare, order and computerize various areas' (Guattari 2009: 268) - or 'qualify' in the language of ANT - because in all of these instances such factors are themselves internally connected to immanent capitalist processes of 'machinic exploitation' and 'machinic surplus value of the code' (Guattari 2009: 268).

What can be inferred from these observations is that Callon's theory of the qualification of products, based as it is within a theory of codes, fails to fully appreciate how capitalism is premised on the logic of abstract equivalences, or decoded life. The axiomatic decoded nature of capital, namely $\mathrm{M}-\mathrm{C}-\mathrm{M}^{1}$ (money buying commodities to make more money), establishes social relations without limitations, as in the constant necessity to generate surplus value, and imposes a universal, abstract and decoded quantity of measurement on all of society (Deleuze and Guattari 1984: 270). As a result, coded STAs are not the cause capitalism but are rather immanent moments in the drive to accumulate decoded quantities of surplus value. 'Knowledge, information, and specialised education are just as much parts of capital ('knowledge capital') as is the most elementary labour of the worker' (Deleuze and Guattari 1984: 255). Given this, it should come as no surprise that those like Callon who believe that the 'new' technological economy is now dominant often fetishise the very economic processes they originally sought to expose. For example, some evidence suggests that GDP growth rate of the new (technological) economy in the USA was 3.01 percent in the 1990s but this was below the more than 4 percent growth rates of the 1950s and 1960s and the 3.26 percent in the 
1970s. By 2001 the growth rate of the new economy stalled at merely 1.2 percent (Harms and Knapp 2003: 416; see also Glyn 2006; Sweet and Meiksins 2008; Turner 2008).

Third, and related to the previous point, by refusing to explore the underlying virtual capacities and powers of capitalist social relations ANT also abstracts away from those crisis tendencies of capital that define the terrain for concrete and contingent problems and dilemmas of economic markets in the first place. A crisis in the economy for ANT is a crisis of actants in economic networks. '(T)he crucial point is not that of the intrinsic competencies of the (economic) agent but that of the equipment and devices which give his/her actions a shape' (Callon 1999: 191). Callon for instance argues that one way a business makes a particular good attractive to a consumer is to 'singularize' the good in question by 'objectifying' its specific qualities in a market. Singularization might occur through socio-cognitive arrangements (e.g. how a product is advertised and packaged) and through the actions of suppliers (e.g. specialists who test the product). Importantly, Callon also recognises that problems evident in economic markets are created to an important degree by a breakdown in coordination across time and space between actants involved in the singularization of a product at different stages in supply and demand networks (Callon et al. 2005: 35-8). That is to say, economic actants encounter a plethora of ongoing uncertainties 'about the states of the world, on the nature of the actions which can be undertaken, and on the expected consequences of these actions...' (Callon 1999: 184).

Callon subsequently displaces the immanent and contradictory social determinates of 
capital onto processes of singularization so that these are then believed to act as if they constitute some of the major problems of and for capitalism. Disavowing the alienated capitalist form of economic markets (cf. Slater 2002: 235 and 238) therefore moves Callon to endorse a theory of crisis based on 'a logic of "spurious infinity": no final resolution, just the endless process of complex partial displacements' (Žižek in Butler et al.: 2000: 111) as concrete-contingent actants are repeatedly enrolled and translated into new 'realities' and new dilemmas (see Gad and Jensen 2010: 71). An economic crisis is then conceived of as a crisis of concrete-contingent actants in empirically observable axes of coordination. Nevertheless, if singularization is indeed believed to constitute one important cause in how economic markets function then presumably simply fixing how economic actor-networks are singularized must simultaneously help to 'fix' some of the problems of contemporary capitalist markets.

Difficulties with this type of explanation are even more pronounced when one considers the current global economic crisis. Evidence suggests that the principle reason why many non-financial firms have sought to gain a higher share of revenue from financial sources such as interest and dividends is due to industrial stagnation in the USA and elsewhere and whose roots lie in immanent contradictions of the overaccumulation of industrial capital during the postwar years until the 1970s. In fact, the hegemonic expansion of financial capital from these immanent processes has to a large extent underpinned the contradictory expansion of the so-called new economy studied by theorists such as Callon (see Brenner 2002; Duménil and Lévy 2002; Krippner 2005; Magdoff and Sweezy 1987; Magdoff and Yates 2009; Milberg 2008; Orhangazi 2008). And such is the hegemony of 
financial capital in the current global economic crisis that 'any serious attempt to rein in the financial system risks destabilizing the whole regime of accumulation, which constantly needs financialization to soar to even higher levels' (Foster and Magdoff 2009: 108). Callon's insights on crises in economic markets fails to fully register how these contradictions fold over and are refracted into distinctive 'economic' planes of immanence and planes of organisation.

\section{Conclusion}

It is often said by actor-network theorists that Deleuze and Guattari work along the same conceptual trajectory as ANT. Law for example observes that Deleuze and Guattari pursue a similar approach to ANT on the 'idea that relations perform or express different and non-conformable spatialities' (Law 1999: 7; see also Latour 2005: 129). But while there are indeed obvious affinities between both this paper has argued that important differences can also be noted. Consider how ANT and Deleuze and Guattari define capitalism. ANT prefers to explore capitalism through concrete-contingent relations that constantly move and circulate through objects like 'documents, stories, accounts, goods, and passions' (Latour 2005: 179). In Anti-Oedipus, and following Marx, Deleuze and Guattari favour a definition of capitalism based on two 'principal elements':

On one side, the deterritorialized worker who has become free and naked, having to sell his labour capacity; and on the other, decoded money that has become capital and is capable of buying it (Deleuze and Guattari 1984: 245). 
At first glance it might appear to be the case that Deleuze and Guattari are beginning their analysis from an opposite spectrum to that of ANT in the sense that they start at an abstract level. But this assumption would be wrong. What Deleuze and Guattari want to highlight, instead, is how capitalism is founded on a decoded and deterritorialized flux in which capital becomes an immanent system - 'as an axiomatic of abstract quantities' (Deleuze and Guattari 1984: 249) - which must at the same time embody concrete and contingent social relations in order to realise surplus value (see Deleuze 2004: 267). As we have seen, ANT explicitly rejects this dialectical position in favour of focusing solely on how concrete-contingent networks are assembled. Unfortunately, this theoretical and methodological standpoint ultimately leads ANT to portray capitalist social relations 'as relations between material objects, instead of revealing them plainly' (Marx 1988: 1689).

This is not to deny that useful insights about the workings of capitalism can be gained through ANT. Founders of ANT however advise fellow enthusiasts to stay only at a concrete-contingent level of abstraction when researching society. The paper has therefore concentrated its energies on criticising this one-sided analysis of capitalist societies. Indeed, many other ANT researchers acknowledge the same problem, as when they draw on neo-Foucauldian strands of social theory which stress the importance of analysing socio-historical formations like neoliberalism (see for example Friedman 2010; see also Miller 2008: 59), or when they use Marxist concepts such as Gramsci's concept of hegemony (Boden et al 2009) or Marx's concept of mode of production (Gille 2010). Such theoretical manoeuvres imply the recognition within ANT itself of the inherent 
limitations involved in producing a critical social science by only utilising a concretecontingent method of abstraction.

The Marxist poststructuralism of Deleuze and Guattari is also interesting because its dialectical synthesis of an abstract and concrete analysis can help to understand how the exploitative tendencies of capital become naturalised. According to Deleuze and Guattari what is unique about capitalism is that as an immanent system in which both human surplus value (e.g. labour productivity) and machinic surplus value (e.g. technology and science) assemble specific drives, or impulses, capital invests our desires, or capacity to act, in specific concrete ways that we often remain unaware of. As Smith (2007: 9) suggests, desire is different from interest in this respect. Interest usually refers to consciously executed goals such as an interest to work hard to gain promotion in a job. ANT often explores a version of this type of 'interest'; for example, when they show how the interests of managers in an organisation are translated to other employees through actants even if unintended and contingent outcomes result. Desire, however, refers to the unacknowledged investment that a person or group already has in a system like capitalism before an interest is consciously pursued. The organisation of desire makes the social system of capitalism appear natural to such an extent that workers frequently no longer appear to be alienated or robbed by capital (Deleuze and Guattari 1984: 259). Therefore what Marxist poststructuralism is particularly good at demonstrating is that while the interests enrolled in concrete-contingent networks are assembled in particular ways it is still nevertheless the case that deep rooted desires operating at different levels of abstraction and through different planes of immanence contain logics that often go 
unnoticed by those who refuse to incorporate abstract dynamics of capitalism in their respective analyses.

\section{References}

Albritton, R. (2007) Economics Transformed, London: Pluto.

Alcadipani, R. and Hassard, J. (2010) 'Actor-Network Theory, Organizations and Critique: Towards a Politics of Organizing', Organization 17(4): 419-435.

Alcouffe, S., Berland, N., and Levant, Y. (2008) 'Actor-Networks and the Diffusion of Management Accounting Innovations: A Comparative Study', Management Accounting Research 19(1): 1-17.

Amin, A. (2004) 'Regulating Economic Globalization', Transactions of the Institute of British Geographers 29: 217-233.

Barnes, T.J. (2008) 'Making Space for the Economy: Live Performances, Dead Objects, and Economic Geography', Geography Compass 2(5): 1432-1448.

Baxter, J. and Chua, W. F. (2003) 'Alternative Management Accounting Research Whence and Whither', Accounting, Organizations and Society 28 (2-3): 97-126.

Bhaskar, R. (1978) A Realist Theory of Science, second edition, Brighton: Harvester Wheatsheaf.

Boden, R, Epstein, D. and Latimar, J. (2009) 'Accounting for Ethos or Programmes for Conduct? The Brave New World of Research Ethics Committees', The Sociological Review 57(4): 727-749.

Brenner, R. (2002) The Boom and the Bubble: The US and the World Economy, London, Verso. 
Brown, A. (2008) 'A Materialist Development of Some Recent Contributions to the Labour Theory of Value', Cambridge Journal of Economics 32(1): 125-146.

Bryer, R. (2006) 'Accounting and Control of the Labour Process', Critical Perspectives on Accounting 17: 551-598.

Büscher, M. and Urry, J. (2009) 'Mobile Methods and the Empirical', European Journal of Social Theory 12(1): 99-116.

Butler, J., Laclau, E. and Žižek, S. (2000) Contingency, Hegemony, Universality, London: Vero.

Callon, M. (1999) 'Actor-Network Theory - The Market Test', in J. Law and J. Hassard (eds), Actor Network Theory and After, Oxford: Blackwell.

Callon, M. (2007) 'An Essay on the Growing Contribution of Economic Markets to the Proliferation of the Social', Theory, Culture and Society 24(7-8): 139-163.

Callon, M., Méadel, C. and Rabeharisoa, V. (2005) 'From Calculation to Alienation: Disentangling Economic Abstractions' in A. Barry and D. Slater (eds) The Technological Economy, London: Routledge.

Callon, M. and Muniesa, F. (2005) 'Economic Markets as Calculative Collective Devices', Organization Studies 26(8): 1229-1250.

Castree, N. (2002) 'False Antitheses? Marxism, Nature and Actor-Networks', Antipode 34(1): 119-148.

Clark, G. L., Thrift, N. and Tickell, A. (2005) 'Performing Finance: The Industry, the Media and its Image' in A. Barry and D. Slater (eds), The Technological Economy, London: Routledge.

Clegg, S.R. (1989) Frameworks of Power, London: Sage. 
Cuganesan, S. (2008) 'Calculating Customer Intimacy: Accounting Numbers in a Sales and Marketing Department', Accounting, Auditing and Accountability Journal 21(1): 78-103.

Dean, K., Joseph, J., Roberts, J.M. and Wight, C. (2006) Realism, Philosophy and Social Science, London: Palgrave.

Deleuze, G. (2007) Two Regimes of Madness, ed. D. Lapoujade, trans. A. Hodges and M. Taormina, New York: Semiotext(e).

Deleuze, G. and Guattari, F. (1984) Anti-Oedipus: Capitalism and Schizophrenia, trans. R. Hurley, M. Seem and H. R. Lane, London: Athlone Press.

Deleuze, G. and Guattari, F. (1988) A Thousand Plateaus, trans. Brian Massumi, London: Althone Press.

Deleuze, G. and Guattari, F. (1994) What is Philosophy? trans. Graham Burchill and Hugh Tomlinson, London: Verso.

Dimoulis, D. and Milios, J. (2004) ‘Commodity Fetishism vs. Capital Fetishism: Marxist Interpretations vis-à-vis Marx's Analyses in Capital', Historical Materialism 12(3): 3-42.

Dolwick, J.S. (2009) 'The “Social” and Beyond: Introducing Actor-Network Theory', Journal of Maritime Archaeology 4(1): 21-49.

Doogan, K. (2001) 'Insecurity and Long-term Employment', Work, Employment and Society 15(3): 419-441.

Doogan, K. (2009) New Capitalism? The Transformation of Work, Cambridge: Polity. Duménil, G. and Lévy, D. (2002) 'The Nature and Contradictions of Neoliberalism' in L. 
Panitch and C. Leys (eds), Socialist Register 2002: A World of Contradictions, London: Merlin Press.

Finch, J. H. (2007) 'Economic Sociology as a Strange Other to both Sociology and Economics', History of the Human Sciences 20(2): 123-140.

Fine, B. (2003) 'Callonistics: A Disentanglement', Economy and Society 32(3): 478-484.

Fine, B. (2005) 'From Actor-Network to Political Economy', Capitalism, Nature, Socialism 16(4): 91-108.

Foster, J. B. and Magdoff, F. (2009) The Great Financial Crisis, New York: Monthly Review Press.

Fox, S. (2000) 'Communities of Practice, Foucault and Actor-Network Theory', Journal of Management Studies 37(6): 853-867.

Frandsen, A-C (2009) 'From Psoriasis to a Number and Back', Information and Organization 19: 103-128.

Friedman, D. (2010) 'A New Mentality for a New Economy: Performing the Homo Economicus in Argentina', Economy and Society 39(2): 271-302.

Gad, C. and Jensen, C. B. (2010) 'On the Consequences of Post-ANT', Science, Technology and Human Values 33(1): 55-80.

Geertz, C. (1993) The Interpretation of Cultures, London: Fontana Press.

Gibson-Graham, J.K. (2006) A Postcapitalist Politics, Minneapolis: Minnesota Press. Gillle, Z. (2010) 'Actor Networks, Modes of Production and Waste Regimes: Reassembling the Macro-social', Environment and Planning A 42(5): 1049-1064. Glyn, A. (2006) Capitalism Unleashed: Finance, Globalization, and Welfare, Oxford: Oxford University Press. 
Gramsci, A. (1986) Selections from Prison Notebooks, London: Lawrence and Wishart.

Granovetter, M. (1984) 'Economic Action and Social Structure: The Problem of Embeddedness', American Journal of Sociology 91: 481-510.

Green, F. (2006) Demanding Work: The Paradox of Job Quality in the Affluent Economy, Princeton, NJ: Princeton University Press.

Guattari, F. (2009) Soft Subversions, Los Angeles, CA: Semiotext(e).

Hadden, R. W. (1994) On the Shoulders of Merchants: Exchange and the Mathematical Conception of Nature in Early Modern Europe, New York: SUNY.

Hardt, M. and Negri, A. (2000) Empire. Cambridge, Mass.: Harvard University Press. Harms, J.B and Knapp, T. (2003) 'The New Economy: What's New, What's Not', Review of Radical Economics 35(4): 413-436.

Harvie, D. and Milburn, K. (2010) 'How Organizations Value and How Value Organizes', Organization 17(5): 631-636.

Holifield, R. (2009) ‘Actor-Network Theory as a Critical Approach to Environmental Justice: A Case against Synthesis with Urban Political Ecology', Antipode 41 (4): 637-658, 2009.

Hudson, R. (2008) 'Cultural Political Economy Meets Global Production Networks: A Productive Meeting?' Journal of Economic Geography 8: 421-440.

Jensen, C. B. (2007) 'Infrastructure Fractals: Revisiting the Micro-Macro Distinction in Social Theory', Environment and Planning D: Society and Space 25: 832-850.

Jessop, B. (1990) State Theory, Cambridge: Polity.

Jones III, J.P., Woodward, K. and Marston, S.A. (2007) 'Situating Flatness’, Transactions of the Institute of British Geographers 32: 264-276. 
Kaidesoja, T. (2007) 'Exploring the Concept of Causal Power in a Critical Realist Tradition', Journal for the Philosophy of Social Behaviour 37(1): 63-87.

Kirsch, S. and Mitchell, D. (2004) 'The Nature of Things: Dead Labor, Nonhuman Actors, and the Persistence of Marxism', Antipode 36(4): 687-705.

Krippner, G.R. (2005) 'The Financialization of the American Economy', SocioEconomic Review 3: 173-208.

Larrain, J. (1983) Marxism and Ideology, London: Macmillan.

Latour, B. (2004) 'Why Has Critique Run out of Steam? From Matters of Fact to Matters of Concern', Critical Inquiry 30(Winter): 225-248.

Latour, B. (2005) Reassembling the Social, Oxford: Oxford University Press.

Law, J. (1991) 'Power, Discretion and Strategy' in J. Law (ed.) A Sociology of Monsters, London: Routledge.

Law, J. (1999) ‘After ANT: Complexity, Naming and Topology' in J. Law and J. Hassard (eds), Actor Network Theory and After, Oxford: Blackwell.

Law, J. (2003) 'Notes on the Theory of the Actor Network: Ordering, Strategy and Heterogeneity', published by the Centre for Science Studies, Lancaster University, $\quad$ Lancaster LA1 4YN, at http://www.comp.lancs.ac.uk/sociology/papers/Law-Notes-on-ANT.pdf

Law, J. and Urry, J. (2004) 'Enacting the Social', Economy and Society 33(3): 390-410.

Lee, N. and Hassard, J. (1999) ‘Organization Unbound: Actor-Network Theory, Research Strategy and Institutional Flexibility', Organization 6(3): 391-404.

Lowe, A. (2001) 'After ANT - An Illustrative Discussion of the Implications for Qualitative Accounting Case Research', Accounting, Auditing and Accountability 
Journal 14(3): 327-351.

MacKenzie, D. (2004) 'The Big Bad Wolf and the Rational Market: Portfolio Insurance, the 1987 Crash and the Performativity of Economics', Economy and Society 33(3): 303-334.

Mcfall, L. (2009) 'Devices and Desires: How Useful is the "New" New Economic Sociology for Understanding Market Attachment?' Sociology Compass 3(2): 267282.

Magdoff, H. and Sweezy, P. (1987) Stagnation and the Financial Explosion, New York: Monthly Review Press.

Magdoff, F. and Yates, M. D. (2009) The ABCs of the Economic Crisis, New York: Monthly Review Press.

Mayall, M. (2007) 'Attached to their Style: Traders, Technical Analysis and Postsocial Relationships', Journal of Sociology 43(4): 421-437.

Marx, K. (1988) Capital, vol. 1, London: Penguin.

Milberg, W. (2008) 'Shifting Sources and Uses of Profits: Sustaining US

Financialization with Global Value Chains', Economy and Society 37(3): 420451.

Miller, P. (2008) 'Calculating Economic Life', Journal of Cultural Economy 1(1): 51-64

Mouritsen, J., Larsen, H., and Bukh, P.N.D. (2001) 'Intellectual Capital and the "Capable Firm": Narrating, Visualizing and Numbering for Managing Knowledge', Accounting, Organizations and Society, 26, 735-762.

Munro, R. (1999) 'Power and Discretion: Membership Work in the Time of Technology', Organization 6(3): 429-450. 
Newman, S. (2007) Unstable Universalities, Manchester: Manchester University Press.

Orhangazi, Ö. (2008) 'Financialisation and Capital Accumulation in the Non-financial Corporate Sector: A Theoretical and Empirical Investigation on the US Economy: 1973-2003', Cambridge Journal of Economics 32(6): 863-886.

Postone, M. (1986) ‘Anti-Semitism and National Socialism', in A. Rabinbach and J. Zipes (eds.), Germans and the Jews since the Holocaust: The Changing Situation in West Germany, New York and London: Holmes and Meier.

Preda, A. (2007) 'The Sociological Approach to Financial Markets', Journal of Economic Surveys 21(3): 506-533.

Read, J. (2003) The Micro-Politics of Capital, New York: SUNY.

Roberts, J. M. (2008) 'Public Spaces of Dissent', Sociology Compass 2(2): 654-674.

Roberts, J. M. (2009) The Competent Public Sphere, London: Palgrave.

Santos, A.C. and Rodrigues, J. (2009) 'Economics as Social Engineering? Questioning the Performativity Thesis', Cambridge Journal of Economics 33: 985-1000.

Sayer, A. (2009) ‘Who’s Afraid of Critical Social Science?’ Current Sociology 57(6): 767-786.

Sayer, D. (1991) Capitalism and Modernity: An Excursus on Marx and Weber. London: Routledge.

Simakova, E. and Neyland, D. (2008) ‘Marketing Mobile Futures: Assembling Constituencies and Creating Compelling Stories for an Emerging Technology', Marketing Theory 8(1): 91-116.

Slater, D. (2002) 'From Calculation to Alienation: Disentangling Economic Abstractions', Economy and Society 31(2): 234-249. 
Smith, D. W. (2007) 'Deleuze and the Question of Desire: Toward an Immanent Theory of Ethics', Parrhesia 2: 66-78.

Sweet, S. and Meiksins, P. (2008) Changing Contours of Work: Job and Opportunities in the New Economy, Thousands Oaks, CA: Pine Forge Press.

Thrift, N. (2001) “'It's the Romance, Not the Finance, that Makes the Business Worth Pursuing”: Disclosing a New Market Culture', Economy and Society 30(4): 412432.

Tinker, T. (2005) 'The Withering of Criticism: A Review of Professional, Foucauldian, Ethnographic, and Epistemic Studies in Accounting', Accounting, Auditing and Accountability Journal 18(1): 100-135.

Toms, S. (2005) 'Financial Control, Managerial Control and Accountability: Evidence from the British Cotton Industry, 1700-2000', Accounting Organization and Society 30: 627-653.

Turner, G. (2008) The Credit Crunch, London: Pluto.

Whittle, A. and Mueller, F. (2008) 'Intra-Partnership and Enrolment: Building Networks of Ideas', Organization 15(3): 445-462.

Williams, C.C. (2007) Rethinking the Future of Work, London: Palgrave.

Žižek, S. (1997) The Plague of Fantasies, London: Verso.

Žižek, S. (2002) Revolution at the Gates, London: Verso.

Žižek, S. (2009) First as Tragedy, then as Farce, London: Verso. 